\title{
Tipping point(s): informal learning for health librarians in an economic downturn
}

\author{
Dean Giustini
}

\section{Key messages}

(1) Formal learning in classrooms (i.e., workshops, training, conferences) is central to the professional development of health librarians

(2) Other forms of learning may take prominence in the years ahead due to the global economic crisis and new curbs on spending for continuing education

(3) The rise of digital access, changing roles for health librarians, and new sources of information increase the need for continuous, social and incidental learning

(4) Health librarians should consider "informal" learning spaces (such as blogs, wikis, Twitter, and "Second Life") to supplement their formal learning

\section{Introduction}

Learning informally may be a more efficient use of time and money — [and may] offer a more attractive alternative to formal classroom-based learning [1].

In this third column of the teaching and learning (T\&L) series, I turn my attention to the continuing education (CE) needs of health librarians and the issues we face with respect to learning during difficult economic times.

You may remember that the T\&L series began with an exploration of three teaching theories: behaviourism, constructivism, and situated-learning [2]. These pedagogical theories, used by instructors to devise strategies for learning, provide a decision framework for workshop planning. If used in combination with teaching experience and evidence from the literature, they form the basis from which all instructional planning begins.

In column 2, we considered some strategies to assist health librarians in the design of learner-centred classrooms [3]. Using a 1.5 hour PubMed workshop as a starting point, the learning needs of a mixed group of users were examined. However, in the absence of a formal class on PubMed to attend, how might my own learning needs be addressed during my planning?

In terms of preparation, this can happen informally, and some of you may be doing this naturally. Some ideas include working online asynchronously with a group of health librarians using a blog or wiki or setting up a conference call using Skype or other tool to discuss the new features of
PubMed. Perhaps a blogger has already evaluated the interface and posted his thoughts for readers. Doing a quick search of Twitter may also lead you to what other health librarians are saying. Even though these informal learning spaces do not replace going to a good PubMed workshop led by a skilled health librarian, they can still provide ways to direct your learning.

The purpose of this paper is to explore some of these informal learning strategies and to devise new, inexpensive ways to direct our lifelong learning. This is increasingly important as the global economic crisis deepens, and new curbs on spending further limit our ability to attend formal workshops.

\section{New global paradigms}

The backdrop to any discussion of learning these days is the recognition that globalization has changed our world and the world of libraries [4,5]. How many of you have noticed a major change in the use of your library in the last few years? I certainly have. My duties at the University of British Columbia Library and the roles I assume as an academic hospital librarian are changing around me as fewer clinicians come into my library and consult its print collections.

Even though it is difficult to tell whether globalization or digitization is leading the revolution, the cumulative effect is now undeniable. In the past, when faced with paradigmatic change, health librarians have adapted quickly and found new roles for themselves. But now health libraries are closing and we are losing positions [6,7]. We may not yet be in crisis mode, but we are certainly seeing some troubling signs.

My purpose here is not to sound dire. Health librarians are resilient and know how to manage change. But our ability to adapt to the new digital realities of the 21 st century and the requirements brought about by lifelong learning is paramount. Consequently, the Canadian Health Libraries Association / Association des bibliothèques de la santé du Canada (CHLA / ABSC) may want to consider investing further in the kinds of online courses we see elsewhere (see Appendix A). Flexible learning options (anytime, any-

D. Giustini. Biomedical Branch Library, Gordon and Leslie Diamond Health Care Centre, University of British Columbia,

2775 Laurel Street, Floor 2, Vancouver, BC V5Z 1M9, Canada (e-mail: dean.giustini@ubc.ca). 
where) and modular formats created elsewhere can help us to avoid reinventing the wheel.

Finally, dealing with a lack of time is a significant barrier that must be addressed. Based on my own experiences, I find that I often focus on the needs of others and neglect my own needs. Setting aside time (and being intentional about it) is important. According to one author, learning how to manage time is based on a set of skills and psychological factors [8]. Any ideas to help us deal with time issues are worth sharing.

\section{Technology evangelism}

As a technology evangelist, I feel the need to promote the use of social media (i.e., blogs, wikis, podcasts, and, increasingly, virtual environments). The tools that I use on a daily basis, such as blogs, wikis, and Twitter, give structure and impetus to my learning. As a platform for e-learning, they also help me to collaborate with other librarians.

Remember that e-learning is not meant to replace face-to-face learning. But educators believe that social media is changing how we communicate and learn in the digital age [9]. At the very least, we should evaluate its benefits and articulate its value (or lack thereof) based on our collective experiences.

With seemingly no evaluation tools or evidence base to justify the use of social media, our field has explored these tools cautiously. However, the Medical Library Association (MLA) and its Web-based courses are useful starting points for anyone new to social media [10]. While social media is seen as a way to network, it is also seen as a space for learning "on-the-go", especially if you have an iPhone or other mobile device [11].

\section{I blog therefore I learn}

The advent of new technologies means the space for informal learning is constantly developing; wikis, blogs, and social networking sites can now be accessed through mobile phones and Web access, thus connecting "virtual and physical spaces" [1].

Information technologies open up new possibilities for learning. On a daily basis, I use social media to bridge my online and offline bibliographic activities. I use Twitter to exchange ideas with librarians, physicians, and a range of technology experts. Without a network of contacts and "tweeps", I would fall behind and lose a major outlet for my continual learning.

How do I use these tools? I begin each day by browsing my RSS feeds. Between appointments and talking to physicians, I reflect on what my users are saying online and in the library. In preparation for writing on my blog, I see what my networks are saying and try out some new ideas with colleagues from around the world.

Many librarians do not have the time or inclination to engage with social media. This is understandable given the priority that is placed on meeting deadlines and day-to-day activities. But be aware that new ways of communicating can raise your profile within your organization. Health librarians who set aside time to explore emerging channels of information can build a basic understanding of what takes place there. These skills might even save your position during a time of cutbacks.

Using a combination of exploration and reflection, it is possible to develop new informal learning competencies. Remember you do not have to author a blog to engage in reflective practice; this can be done informally by keeping a journal or diary [12].

\section{Informal learning and reduced budgets}

The world is facing the worst fiscal crisis since the Great Depression [13]. Fewer countries (including Canada) have the needed revenues to spend on programs and services, and governments at all levels will be trimming their operating budgets for the foreseeable future.

Some American hospitals are taking drastic steps and closing libraries — what Stephen Abrams calls "a special kind of stupid" [14]. I agree with Abrams but also agree with the American health librarian Michelle Kraft that the viability of hospital libraries depends on the skills of the professional, which must be kept current [7].

Funding cuts will deepen as the global recession affects organizational spending and library budgets. Hospital library closures are the beginning of what a contracting global economy might bring to health care.

So how do we keep learning in this environment? The state of the economy raises some important questions:

(i) How do we maintain or build our information skills in uncertain times?

(ii) Can we take advantage of other forms of learning, for example, using online tools?

(iii) Are there best practices that can help us to adapt to this new world?

(iv) In the absence of formal learning opportunities (i.e., attendance at conferences), what informal and inexpensive alternatives are available?

In 2009, the curb on funding has resulted in lower conference attendance. The American Libraries Association (ALA) did not draw the crowds it anticipated for its ALA MidWinter Conference [15]. Others have seen a 30\% drop in conference attendance [16].

The MLA says its conference saw a drop in attendance this year. In fact, President Connie Schardt said that $46 \%$ of the MLA membership has been to "just one or no annual conference in the last 5 years" (C. Schardt, personal communication, July 2009). This is a worrying trend, she says; one of her goals as incoming president is to find new ways to connect with MLA members using online meeting technologies.

Overall attendance at the 2009 CHLA / ABSC conference was also down. Some CE workshops had to be cancelled due to low registration and high costs. Reduced professional development funds for health librarians is one reason why conference attendance is down. These cancelled programs represent hours of wasted time and effort on the part of members, something we can ill afford to do again.

In the years ahead, travel to conferences will be increasingly difficult for CHLA / ABSC members. Travel across Canada, in many instances, will be a luxury that few can afford. Our CE coordinator, Lindsay Glynn, will undoubtedly 
be looking at these issues. But we can begin to share ideas about what is strategic and sustainable in the future.

\section{Tipping point(s) and informal learning}

The idea of a "tipping point" was popularized by Malcolm Gladwell's 2000 bestseller of the same name [17]. A tipping point is "the point at which small changes occur in rapid succession to produce unpredictable results."

Some librarians believe that we are seeing a tipping point in $\mathrm{CE}$ funding. But if we cannot attend conferences or sign up for courses, what will we do? Our ability to attend conferences depends on several factors. But it may be time to consider whether the current model of spending large sums to attend annual conferences is sustainable. We need to examine these issues and articulate what we want for the future.

There is a considerable body of literature around the value of learning in real contexts. The importance of situated learning can be seen in health care where interactions among physicians and other health professionals makes learning direct and immediate - and informal (Appendix B).

Do the principles and mindset of informal learning offer any solutions for our field? Here are the main attributes that define informal learning (IL):

(i) IL is a process by which we acquire and accumulate new knowledge, skills, attitudes

(ii) Takes place outside formal classrooms and does not follow a plan

(iii) Not professionally organized but happens accidentally, episodically, haphazardly

(iv) Often incidental, holistic, and related to working with others in situ on projects [18-20].

The deep, rich informal learning that takes place among health workers - given a shared repertoire of patient care and evidence-based practice - is a wonderful example of situated learning. According to a landmark study, informal learning accounts for a lot of the individual learning that takes place in organizations [21].

Let's brainstorm how health librarians might promote their own informal learning practices.

\section{Brainstorming informal learning}

In the absence of monies to attend conferences and formal workshops, it is critical that health librarians seek creative solutions to learn during the recession. The following are suggestions based on some brainstorming with colleagues and students. Obviously, many are already in use but bear repeating:

(1) Discover what informal learning options are available in your local community: $(i)$ if you haven't already, participate in your local chapter of CHLA / ABSC; (ii) work with your colleagues to schedule an "unconference" to share ideas; (iii) find out what library conferences are being held locally you can attend; (iv) keep records of your formal, informal, and experiential learning achievements.
(2) Explore new ways of upgrading your skills: $(i)$ participate in free webcasts put on by vendors and library associations; (ii) share knowledge objects found on social media Web sites (i.e., YouTube, bliptv); (iii) start an online journal club with health librarians in your region; (iv) listen to a presentation in Second Life or another online meeting place.

(3) Follow a few Canadian or American health librarian bloggers: (i) for example, Francesca Frati, Daniel Hooker, and Mark Rabnett (or an American blogger); (ii) experiment with social networks as a form of informal learning; (iii) visit the CHLA / ABSC Web site regularly.

(4) Mentor a health librarian student or colleague: (i) ask CHLA / ABSC to find you a library school student in your area; (ii) enjoy the benefits of two-way mentoring, a great source of mutual support and feedback; (iii) partner with someone to do some research in health librarianship.

(5) Create your own blog or online writing space: (i) blogs instill the discipline of reading, writing, and thinking; (ii) blogs can be used as a platform to share ideas and new information; (iii) health librarian bloggers are few and far between; if you write well, you can quickly build followers.

\section{Conclusions}

Informal learning will never replace formal learning. Within the context of CHLA / ABSC and the annual conference - arguably the most important event of the year for most health librarians in Canada - it may be time to consider online alternatives to attending in person. It may also be time to devise a "no health librarian left behind" policy for members whose CE funds are so woefully inadequate that they can never attend.

To focus attention on building our professional competencies, it may be time to consider licensure. Similar to the MLA Academy of Health Information Professionals program, a Canadian program could be more affordable and cater specifically to our work in Canada. To promote health librarians (and the unique skills we bring) we may even want to use this as an opportunity to change our name to the "Canadian Health Librarians Association / Association des bibliothécaires de la santé du Canada". While a name change may seem trivial to some, think of it as part of an overall strategy to market and emphasize our information skills in the digital age. This may be even more important given that physical libraries have diminished in importance in recent years.

In summary, our multipronged approach to continuing education should coincide with a major shift in our daily information practices. We can begin by finding less expensive online alternatives (i.e., VOIP, Skype, chat, video and teleconferencing) in lieu of attending conferences in person. Finally, we may need to find additional sponsorship and financial support for future annual conferences to make them as affordable as possible for our members.

\section{References}

1. Halliday-Wynes S, Beddie F. Informal learning: at a glance. National Centre for Vocational Education Research (NCVER), Commonwealth of Australia; 2009. 
2. Giustini D. Part I. Utilizing learning theories in the digital age: an introduction for health librarians. J Can Health Libr Assoc. 2008 Sep;29:109-15.

3. Giustini D. Part II. Utilizing learning theories in the digital age: from theory to practice. J Can Health Libr Assoc. 2009 Mar;30:19-25.

4. Madge B, Plutchak S. The increasing globalization of health librarianship: a brief survey of international trends and activities. Health Info Libr J. 2005;(22 Suppl 1):20-30.

5. Medical Library Association (MLA) and the Association of Academic Health Sciences Libraries (AAHSL). Statement on the Global Economic Crisis and its Impact on Health Sciences Library Collections. 2009 May. Available from: http://www. mlanet.org/government/gov_pdf/2009_may_glbleconcrisis_ statement.pdf.

6. Garrigan M. Hospital library closes to public, goes electronic. Rapid City Journal. 2009 Jun 9.

7. Kraft M. Why is the hospital library disappearing? Krafty Librarian blogpost. 2009 Jun 17. Available from: http:// kraftylibrarian.com/?p=53.

8. Zimbardo P, Boyd J. The time paradox: the new psychology of time that will change your life. New York: Free Press; 2008.

9. Jones A, Issroff K, Scanlon E, Clough G, McAndrew P. Using mobile devices for learning in informal settings. In: IADIS International Conference on Mobile Learning 2006; $2006 \mathrm{Jul}$ 14-16; Dublin. Available from: http://www.iadis.net/dl/final_ uploads/200605S036.pdf.

10. Medical Library Association. Task Force on Social Networking Software. Available from: http://sns.mlanet.org/blog/.

11. Sontag, M. A learning theory for 21 st-century students. Innovate. 2009 Apr-May;5(4). Available from: http://www. innovateonline.info/index.php?view $=$ article $\& i d=524$.
12. Doherty J. Towards self-reflection in librarianship: what is praxis? Prog Libr. 2005;26:11-8.

13. Crutsinger M. US budget deficit tops $\$ 1$-trillion for the first time. Globe and Mail. Report on Business. 2009 Jul 13.

14. Abrams S. A special kind of stupid - closing a hospital library. Stephen's Lighthouse. Available from: http://tinyurl. com/lmqrx6.

15. Oder N. ALA MidWinter Conference Report: Denver Attendance Drops. 2009 Feb 15. Available from: http://www. libraryjournal.com/article/CA6634726.html.

16. American Library Association. AL Scoop blog. Recession drives membership numbers downward. 2009 Jul 7. Available from: http://www.al.ala.org/insidescoop/2009/07/07/recessiondrives-membership-numbers-downward/.

17. Gladwell M. The tipping point: how little things can make a big difference. Little, Brown and Company; 2000.

18. Merriam S, Caffarella R, Baumgartner L. Learning in adulthood: a comprehensive guide. 3rd ed. New York: Wiley; 2007.

19. McGiveney V. Informal learning in the community: A trigger for change and development. Leicester: NIACE; 1999. (Report of a study that focuses on the role of informal learning in "starting people on a learning pathway").

20. Cross J. Informal Learning: rediscovering the natural pathways that inspire innovation and performance. San Francisco: Jossey-Bass; 2006.

21. Livingstone D. Exploring the icebergs of adult learning: findings of the first Canadian survey of informal learning practices. Toronto: OISE; 2000. Available from: http://www.oise. utoronto.ca/depts/sese/csew/nall/res/10exploring.htm.

\section{Appendix A}

The following are some continuing education sites for health librarians:

(1) CHLA / ABSC Continuing Education blog (http://www.chla-absc.ca/?q=en/blog/)

(2) European Association for Health Information and Libraries - Web 2.0 Taskforce (http://tw2eahil.blogspot.com/)

(3) Medical Library Association - Continuing Education (http://www.mlanet.org/education/index.html)

(4) UBC Health Library wiki - Teaching Health Library Users (http://hlwiki.slais.ubc.ca/index.php/Teaching_health_library_ users)

\section{Appendix B}

Table B1. Formal-informal learning continuum.

\begin{tabular}{lcc}
\hline "Formal learning" is & "Non-formal learning" is & "Informal learning" is \\
\hline Learning in a program, usually & Learning in a program that & Learning outside a program in situ \\
in a classroom, educational & may be formal but & as in discussion on-the-job, \\
setting, training centre, or & where participants are not & reflecting on daily experiences, \\
continuing education context & evaluated or certified as a & mentoring, and being mentored \\
& consequence & \\
\hline
\end{tabular}


This article has been cited by:

1. 2010. Full Issue in PDF / Numéro complet enform PDF. Journal of the Canadian Health Libraries Association 31:1, 1-24. [Citation] [PDF] [PDF Plus]

2. Dean Giustini. 2010. Evidence-based teaching (EBT) and health librarians: some questions and considerations. Journal of the Canadian Health Libraries Association 31:1, 7-10. [Citation] [PDF] [PDF Plus] 